\title{
Clostridium perfringens $\alpha$-toxin induces rabbit neutrophil adhesion
}

\author{
Sadayuki Ochi, Toshihumi Miyawaki, Hisaaki Matsuda, Masataka Oda, \\ Masahiro Nagahama and Jun Sakurai
}

Department of Microbiology, Faculty of Pharmaceutical Sciences, Tokushima Bunri University, Yamashiro-cho, Tokushima 770-8514, Japan
Author for correspondence: Jun Sakurai. Tel: +8188 622 9611. Fax: +81 886553051. e-mail: sakurai@ph.bunri-u.ac.jp

Clostridium perfringens $\alpha$-toxin, which is one of the main agents involved in the development of gas gangrene, stimulates $\mathrm{O}_{2}^{-}$production in neutrophils. Exposure of rabbit neutrophils to the $\alpha$-toxin induced firm adhesion of the cells to fibrinogen and fibronectin. Incubation of rabbit neutrophils and neutrophil lysates with $\alpha$-toxin led to the production of diacylglycerol (DG) and L- $\alpha$ phosphatidic acid (PA), respectively. The toxin-induced DG and PA formation preceded the toxin-induced adhesion of the neutrophils to fibrinogen and fibronectin, and the production of $\mathrm{O}_{2}^{-}$. Pertussis toxin inhibited the $\alpha$-toxininduced formation of PA, the adhesion of the neutrophils to fibrinogen and $\mathrm{O}_{2}^{-}$ production. GTP $\gamma S$ stimulated the events induced by the $\alpha$-toxin, whereas GDP $\beta$ S inhibited them. The $\alpha$-toxin stimulated phosphorylation of a protein with a molecular mass of about $40 \mathrm{kDa}$. In addition, treatment of the cells with 1-oleoyl-2-acetyl-sn-glycerol (OAG) and phorbol-12, 13-dibutyrate (PDBu) stimulated cell adhesion, production of $\mathrm{O}_{2}^{-}$and phosphorylation of the $40 \mathrm{kDa}$ protein, but had no effect on the formation of PA. The events induced by the presence of OAG and PDBu were not inhibited by pertussis toxin. Protein kinase $C$ inhibitors, H-7, staurosporine and chelerythrine, blocked $\alpha$-toxininduced adhesion, production of $\mathrm{O}_{2}^{-}$and phosphorylation of the $\mathbf{4 0} \mathrm{kDa}$ protein. These observations suggested that $\alpha$-toxin-stimulated adhesion to the matrix and $\mathrm{O}_{2}^{-}$production were due to the formation of DG, through activation of phospholipid metabolism by a pertussis-toxin-sensitive GTP-binding protein, followed by activation of protein kinase C by DG.

Keywords: fibrinogen, gas gangrene

\section{INTRODUCTION}

Clostridium perfringens $\alpha$-toxin, which possesses lethal, haemolytic, dermonecrotic and phospholipase C (PLC) activities (Titball, 1993, 1997a, b, 1999; Sakurai, 1995), has been reported to be a major pathogenic factor in the development of gas gangrene caused by the microorganism (Awad et al., 1995; Sakurai, 1995; Titball, 1997b; Bryant et al., 2000a, b). Neutrophils are known to respond to invasion by micro-organisms and to kill them through the generation of reactive oxygen metabolites. Several studies have reported that the $\alpha$-toxin of $C$. perfringens (Patriarca et al., 1970; Stevens et al., 1987;

Abbreviations: DG, diacylglycerol; fMLP, formyl-Met-Leu-Pro; MCLA, 2-methyl-6-( $p$-methoxyphenyl)-3,7-dihydroimidazo(1,2-a)pyrazin-3-one; OAG, 1-oleoyl-2-acetyl-sn-glycerol; PA, L- $\alpha$-phosphatidic acid; PDBu, phorbol-12,13-dibutyrate; PLC, phospholipase C.
König et al., 1997; Hofman et al., 2000), and the PLC of Bacillus cereus (Styrt et al., 1989), activate neutrophils, measured as an increase in $\mathrm{O}_{2}^{-}$formation and enhancement of chemiluminescence induced by opsonized zymosan. However, histopathology has demonstrated an absence of leukocytes within the area of necrosis associated with C. perfringens growth and the presence of these cells at the borders of the region showing necrosis (Robb-Smith, 1945; Stevens et al., 1997). Stevens et al. (1987) reported that the toxin did not alter the viability, chemotactic responsiveness or morphology of human leukocytes. Bryant \& Stevens (1996) reported that exposure to $\alpha$-toxin induced an up-regulation of the expression of intercellular adherence molecule (ICAM1), E-selectin and P-selectin expression, and that exposure to $\theta$-toxin induced ICAM-1 and the production of platelet-aggregating factor by endothelial cells. However, Ellemor et al. (1999) reported that an infection of 
C. perfringens resulted in no increase in ICAM-1. Therefore, little is known about the cause of the paucity of leukocytes within the area of necrosis caused by the micro-organism.

We have previously reported that $\alpha$-toxin induces the contraction of isolated rat aorta (Fujii et al., 1986) and ileum (Sakurai et al., 1990), and that this contraction is related to the turnover of phosphatidylinositol. Notably, the toxin-induced contraction of isolated aorta was found to be closely linked to the stimulation of thromboxane $A_{2}$ synthesis (Fujii \& Sakurai, 1989). We have also reported that incubation of rabbit erythrocyte membranes with the toxin results in a biphasic production of PA and that the rapid formation of PA, induced by the toxin, is due to activation of endogenous PLC regulated by GTP-binding protein, whereas the late formation is dependent on the activation of endogenous phospholipase D (Sakurai et al., 1993, 1994; Ochi et al., 1996). Therefore, to test if $\alpha$-toxin affects the adhesion of rabbit neutrophils to tissues, we compared the effect of the toxin on the adhesion of neutrophils to matrixes. Moreover, we present evidence of a relationship between $\alpha$-toxin-induced adhesion and phospholipid metabolism in rabbit neutrophils.

\section{METHODS}

Purification of wild-type $\alpha$-toxin and the H148G variant. Recombinant plasmids of pHY300PLK harbouring the structural genes of wild-type $\alpha$-toxin or H148G (Nagahama et al., 1995) were introduced into Bacillus subtilis ISW1214 by transformation. Transformants were grown in Luria-Bertani broth containing $50 \mu \mathrm{g}$ ampicillin $\mathrm{ml}^{-1}$ to an $\mathrm{OD}_{600}$ of $0.8-0.85$, with continuous aeration. The culture was centrifuged $(18000 \mathrm{~g}, 20 \mathrm{~min})$ and ammonium sulfate $\left(472 \mathrm{~g} \mathrm{l}^{-1}\right)$ was added to the culture supernatant fluid. The ammonium sulfate fraction obtained was used as the starting material for purifying the toxins. Purification of wild-type toxin and the H148G variant was performed as described previously (Nagahama et al., 1995), and was followed by homogeneity-testing with SDS-PAGE and immunological techniques (Nagahama et al., 1995). The PLC activity of the wild-type $\alpha$-toxin was determined photometrically $\left(A_{405}\right)$ with $p$-nitrophenylphosphorylcholine (Sigma) as the substrate (Kurioka \& Matsuda, 1976). One unit of PLC activity was defined as the amount of enzyme necessary to liberate $1 \mu \mathrm{mol} p$-nitrophenol $\mathrm{min}^{-1}$ from $p$-nitrophenylphosphorylcholine at $37^{\circ} \mathrm{C}$. In this case, one unit corresponds to about $9 \mu$ g of wild-type $\alpha$-toxin. H148G variant toxin bound to sheep erythrocyte membranes and phosphatidylcholine-cholesterol liposomes, but did not contain PLC ( $p$-nitrophenylphosphorylcholine hydrolytic activity), sphingomyelinase, or haemolytic and lethal activity, as reported previously (Nagahama et al., 1995).

Preparation of rabbit neutrophils and cell lysates. Rabbit blood was withdrawn from the ear arteriae of New Zealand White rabbits. Acid citrate-glucose $(0.085 \mathrm{M}$ sodium citrate, $0.065 \mathrm{M}$ citric acid, $2 \%$ glucose) was present in each sample as an anticoagulant. Blood samples were centrifuged at $380 \mathrm{~g}$ for $5 \mathrm{~min}$, and the supernatant containing the leukocytes was collected and mixed with $4.5 \%$ dextran (Amersham) in $0.9 \%$ $\mathrm{NaCl}$. The supernatant (the plasma layer containing the leukocytes) was recovered after $30 \mathrm{~min}$ sedimentation and then centrifuged at $380 \mathrm{~g}$ for $5 \mathrm{~min}$. Contaminated erythro- cytes contained within the pellet were removed by haemolysis with hypotonic ammonium chloride solution $(0.155 \mathrm{M}$ $\mathrm{NH}_{4} \mathrm{Cl}, 0 \cdot 119 \mathrm{M} \mathrm{NaHCO}_{3}, 0 \cdot 1 \mathrm{mM}$ EDTA). Following centrifugation $(380 \mathrm{~g}, 5 \mathrm{~min})$, the white cell pellet was washed and resuspended in Hanks' balanced salt solution without divalent cations (HBSS; $137 \mathrm{mM} \mathrm{NaCl}, 5.36 \mathrm{mM} \mathrm{KCl}, 0.337 \mathrm{mM}$ $\mathrm{Na}_{2} \mathrm{HPO}_{4}, 0.441 \mathrm{mM} \mathrm{KH} \mathrm{PO}_{4}, 4.17 \mathrm{mM} \mathrm{NaHCO}{ }_{3}, 5.55 \mathrm{mM}$ glucose, $\mathrm{pH} 7 \cdot 4)$. The suspended cells were overlaid with lymphoprep (New England Nuclear) and centrifuged at $280 \mathrm{~g}$ for $20 \mathrm{~min}$. The neutrophil pellet was washed and resuspended to a concentration of $1 \times 10^{8}$ cells $\mathrm{ml}^{-1}$ in HBSS. The neutrophils were routinely of high purity $(>90 \%)$ and viability $(>$ $95 \%$ ). Rabbit neutrophil lysates were prepared by sonication; the resulting sonicates were termed the lysate.

Measurement of active oxygen in rabbit neutrophils. The generation of active oxygen was evaluated by the MCLA [2-methyl-6-( $p$-methoxyphenyl)-3,7-dihydroimidazo(1,2-a)pyrazin-3-one]-dependent chemiluminescence method (Nishida et al., 1989; Nakano, 1990). MCLA reacts with $\mathrm{O}_{2}^{-}$or ${ }^{1} \mathrm{O}_{2}$ (singlet oxygen) to emit light, via the dioxetanone analogue. Superoxide dismutase (a scavenger of $\mathrm{O}_{2}^{-}$), or $\mathrm{NaN}_{3}$ (a quencher of ${ }^{1} \mathrm{O}_{2}$ ) can be used for differentiating between $\mathrm{O}_{2}^{-}$ and ${ }^{1} \mathrm{O}_{2}$-dependent luminescence. Thus, MCLA is an excellent chemiluminescence probe for the detection of $\mathrm{O}_{2}^{-}$in terms of its specificity and selectivity. Rabbit neutrophils $\left(1.5 \times 10^{6}\right.$ cells $\mathrm{ml}^{-1}$ ) were incubated with $\alpha$-toxin at $37^{\circ} \mathrm{C}$ in a final volume of $0.2 \mathrm{ml} \mathrm{HBSS}$ containing $0.3 \mathrm{mM} \mathrm{CaCl}_{2}$ and $1.25 \mu \mathrm{M}$ MCLA (Tokyo Kasei Kogyo). The maximal chemiluminescence intensity was determined by measuring its peak height (c.p.m.) using a chemiluminescence reader (luminescencerJNR; Atto, Japan). Xanthine oxidase (XO, Sigma) was assayed by the reduction of ferrocytochrome $c$ (Sigma), in terms of the conversion of hypoxanthine (Wako Pure Chemical Industries) to urate. Briefly, the reaction mixture contained, in a final volume of $0.2 \mathrm{ml} \mathrm{HBSS}, 50 \mu \mathrm{M}$ hypoxanthine and $40 \mu \mathrm{M}$ XO. Adding the $\mathrm{XO}$ at $37^{\circ} \mathrm{C}$ started the reaction and the change in absorbance at $550-540 \mathrm{~nm}$ was monitored by a spectrophotometer. In this case, one unit of XO corresponded to the generation of $0 \cdot 248 \mathrm{nmol} \mathrm{O}_{2}^{-} \min ^{-1}$ and a MCLA-dependent maximal chemiluminescence intensity of 744000 c.p.m.

Measurement of active oxygen in permeabilized rabbit

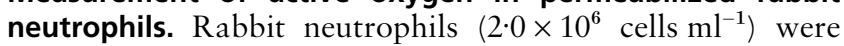
permeabilized in HBSS containing $10 \mu \mathrm{M}$ cytochalasin B (Nacalai Tesque) and $2 \mu \mathrm{M}$ streptolysin O (Sigma) (preactivated by incubation with $0.45 \mathrm{mM}$ dithiothreitol at $37^{\circ} \mathrm{C}$ for $5 \mathrm{~min}$ ) at $37^{\circ} \mathrm{C}$ for $5 \mathrm{~min}$ (at this concentration of streptolysin $\mathrm{O}, 0.9 \pm 0.2 \%$ of the total lactate dehydrogenase activity was released from cells during a 30 min incubation) (Bhakdi \& Tranum-Jensen, 1988). The permeabilized neutrophils $\left(1.5 \times 10^{6}\right.$ cells $\left.\mathrm{ml}^{-1}\right)$ were incubated with $\alpha$-toxin at $37^{\circ} \mathrm{C}$ in HBSS containing $0.3 \mathrm{mM} \mathrm{CaCl}, 1 \mathrm{mM} \mathrm{MgCl}_{2}$, $0.5 \mathrm{mM}$ glutathione (oxidized form) and $1.25 \mu \mathrm{M}$ MCLA in the absence or presence of a guanine nucleotide analogue $(\mathrm{GTP} \gamma \mathrm{S}$ or GDP $\beta$ S, Roche). The chemiluminescence intensity was determined by a chemiluminescence reader.

Measurement of rabbit neutrophil adhesion. The adhesion of neutrophils to extracellular matrixes was evaluated in 24-well tissue culture plates coated with ligand. Prior to the addition of neutrophils, the plates were incubated with $500 \mu \mathrm{l}$ per well of $50 \mu \mathrm{g}$ human fibrinogen $\mathrm{ml}^{-1}$ (Calbiochem-Novabiochem), $50 \mu \mathrm{g}$ bovine type I collagen $\mathrm{ml}^{-1}$ (Sigma) or $50 \mu \mathrm{g}$ bovine fibronectin $\mathrm{ml}^{-1}$ (Nacalai Tesque) for $2 \mathrm{~h}$ at $37^{\circ} \mathrm{C}$. The wells were washed once with HBSS, blocked with $1 \%$ BSA in HBSS for $1 \mathrm{~h}$ at $37^{\circ} \mathrm{C}$, washed twice with HBSS containing $0 \cdot 1 \%$ 

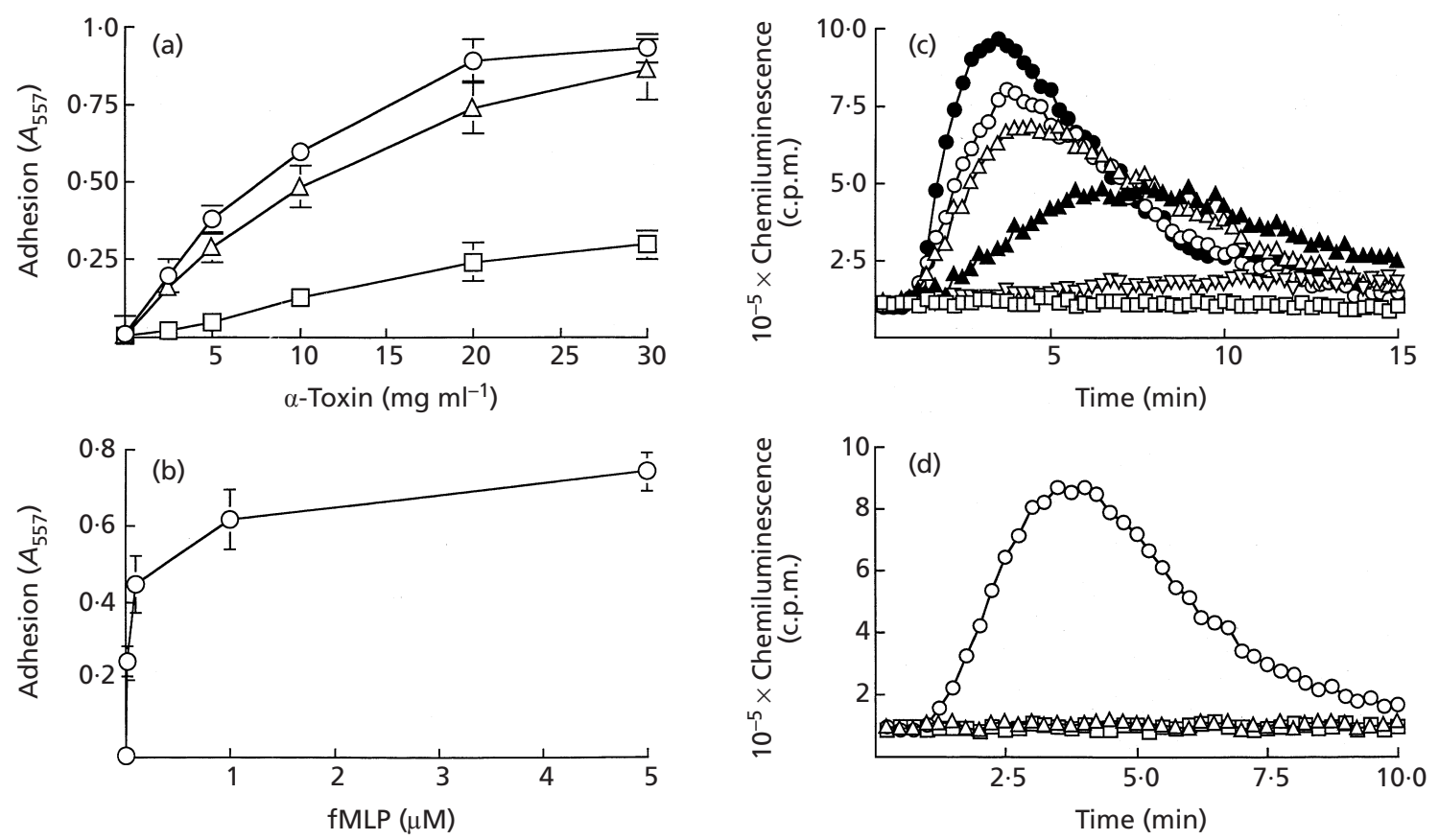

Fig. 1. Effect of $\alpha$-toxin on neutrophil adhesion to fibrinogen and superoxide generation. (a) Rabbit neutrophils $\left(1.2 \times 10^{6} \mathrm{ml}^{-1}\right)$ were incubated with various concentrations of $\alpha$-toxin in fibrinogen- $(O)$, fibronectin- $(\triangle)$ or type I collagen- $(\square)$ coated wells at $37^{\circ} \mathrm{C}$ for $20 \mathrm{~min}$. Values are means \pm SE for five or six experiments. (b) Rabbit neutrophils $\left(1.2 \times 10^{6} \mathrm{ml}^{-1}\right)$ were incubated with various concentrations of fMLP in fibrinogen-coated wells at $37^{\circ} \mathrm{C}$ for $15 \mathrm{~min}$. Adherent cells were determined as described in Methods. Values are means \pm SE for five or six experiments. (c) Rabbit neutrophils $\left(1.5 \times 10^{6} \mathrm{ml}^{-1}\right)$ were incubated without $(\square)$ or with various concentrations of $\alpha$-toxin $\left(\nabla, 1 \mu \mathrm{g} \mathrm{ml}{ }^{-1} ; \boldsymbol{\Delta}\right.$ $\left.2.5 \mu \mathrm{g} \mathrm{ml}^{-1} ; \triangle, 5 \mu \mathrm{g} \mathrm{ml}^{-1} ; \bigcirc, 10 \mu \mathrm{g} \mathrm{ml}^{-1} ; 0,20 \mu \mathrm{g} \mathrm{ml}^{-1}\right)$ at $37^{\circ} \mathrm{C}$ for different periods and the chemiluminescence was measured by a chemiluminescence reader. The results from one of five experiments yielding similar results are shown. (d) Rabbit neutrophils $\left(1.5 \times 10^{6} \mathrm{ml}^{-1}\right)$ were incubated without $(\square)$ or with $10 \mu \mathrm{g}$ wild-type $\alpha$-toxin ml $\mathrm{m}^{-1}(\bigcirc)$ or $100 \mu \mathrm{g}$ $\mathrm{H} 148 \mathrm{G} \mathrm{ml} \mathrm{I}^{-1}(\triangle)$ at $37^{\circ} \mathrm{C}$ for various periods and the chemiluminescence was measured by a chemiluminescence reader. A typical result from one of five experiments is shown.

Tween 20 and then once with HBSS. Rabbit neutrophils

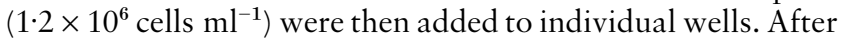
incubation with $\alpha$-toxin in the presence of $0.3 \mathrm{mM} \mathrm{CaCl}_{2}$ for $30 \mathrm{~min}$ at $37^{\circ} \mathrm{C}$, non-adherent cells were gently washed twice with warm PBS (1.06 $\mathrm{M} \mathrm{KH}_{2} \mathrm{PO}_{4}, 2.97 \mathrm{mM} \mathrm{Na}_{2} \mathrm{HPO}_{4} .7 \mathrm{H}_{2} \mathrm{O}$, $154 \mathrm{mM} \mathrm{NaCl}$ ) containing $1 \mathrm{mM} \mathrm{CaCl}$. Adherent neutrophils were then stained with $250 \mu \mathrm{l} 0 \cdot 25 \%$ rose bengal (Wako Pure Chemical Industries) solution for $10 \mathrm{~min}$ at room temperature. The staining solution was aspirated off and each well was washed twice with PBS and then $250 \mu \mathrm{l}$ ethanol/PBS $(1: 1, \mathrm{v} / \mathrm{v})$ solution was added. After incubation at $37^{\circ} \mathrm{C}$ for $30 \mathrm{~min}$, to allow the cell-retained stain to be completely dissolved, the $A_{557}$ of each well was determined with a microplate spectrophotometer (SPECTRAmax 340PC, Molecular Devices), using wells containing medium alone as a control. Cell adhesion to wells coated with BSA was not detected, even when neutrophils were treated with the toxin in the presence of $\mathrm{Ca}^{2+}$.

Measurement of diacylglycerol (DG) and L- $\alpha$-phosphatidic acid (PA) formation induced by $\alpha$-toxin in rabbit neutrophils. For DG measurements, rabbit neutrophils $\left(1.5 \times 10^{7}{\left.\text { cells } \mathrm{ml}^{-1}\right)}^{-1}\right.$ were incubated with $\alpha$-toxin in a final volume of $0.08 \mathrm{ml} \mathrm{HBSS}$ containing $0.3 \mathrm{mM} \mathrm{CaCl}_{2}$ and $1 \mathrm{mM} \mathrm{MgCl}_{2}$ at $37^{\circ} \mathrm{C}$. After the reaction was terminated, by the addition of $0.3 \mathrm{ml}$ chloroform/methanol $(1: 2, \mathrm{v} / \mathrm{v})$, DG was extracted and quantified as previously described (Sakurai et al., 1993). In brief, DG in the extracted lipids was converted into $\left[{ }^{32} \mathrm{P}\right] \mathrm{PA}$ by Escherichia coli DG kinase in the presence of $\left[\gamma^{32} \mathrm{P}\right] \mathrm{ATP} .\left[{ }^{32} \mathrm{P}\right] \mathrm{PA}$ was separated by TLC and measured in a liquid scintillation counter. The amount of DG converted to $\left[{ }^{32} \mathrm{P}\right] \mathrm{PA}$ was calculated based upon the specific activity of $\left[\gamma_{-}{ }^{32} \mathrm{P}\right]$ ATP and the sample volume. A standard curve for the conversion of DG to PA was constructed using known quantities of 1-stearoyl-2arachidonyl-sn-glycerol (Biomol Research Laboratories), and quantitated from the specific activity. A known amount of 1stearoyl-2-arachidonyl-sn-glycerol was run with each assay to quantify the conversion.

For PA measurements, rabbit neutrophil lysates $\left(1.5 \times 10^{7}\right.$ cells $\mathrm{ml}^{-1}$ ) were incubated with $\alpha$-toxin in a final volume of $0.5 \mathrm{ml}$ HBSS containing $0.3 \mathrm{mM} \mathrm{CaCl}, 1 \mathrm{mM} \mathrm{MgCl}_{2}$ and $10 \mu \mathrm{Ci} \mathrm{ml}^{-1}\left(370 \mathrm{kBq} \mathrm{ml}^{-1}\right)\left[\gamma^{-32} \mathrm{P}\right] \mathrm{ATP}$ (ICN Biochemicals) in the presence or absence of a guanine nucleotide analogue $\left(\mathrm{GTP} \gamma \mathrm{S}\right.$ or GDP $\beta S$ ) at $37^{\circ} \mathrm{C}$. After the reaction was terminated by the addition of $0.5 \mathrm{ml}$ ice-cold HBSS and $3.6 \mathrm{ml}$ chloroform/methanol/concentrated $\mathrm{HCl}$ (50:100:1, by vol.), $\left[{ }^{32} \mathrm{P}\right] \mathrm{PA}$ was extracted and quantified as previously described (Sakurai et al., 1993). Briefly, the extracted $\left[{ }^{32} \mathrm{P}\right] \mathrm{PA}$ was separated by TLC and the radioactivity measured in a liquid scintillation counter.

Detection of protein phosphorylation induced by $\alpha$-toxin in rabbit neutrophils. Rabbit neutrophil lysates $\left(1.5 \times 10^{7}\right.$ cells $\mathrm{ml}^{-1}$ ) were incubated with $\alpha$-toxin at $37^{\circ} \mathrm{C}$ for $5 \mathrm{~min}$ in HBSS containing $0.3 \mathrm{mM} \mathrm{CaCl}, 1 \mathrm{mM} \mathrm{MgCl}, 0.1 \mathrm{mM} \mathrm{Na}_{3} \mathrm{VO}_{4}$ and $10 \mu \mathrm{Ci}\left[\gamma_{-}{ }^{32} \mathrm{P}\right] \mathrm{ATP} \mathrm{ml}^{-1}$. After incubation, the reaction was terminated by the addition of $0.5 \mathrm{ml}$ ice-cold $7.5 \%$ 
trichloroacetic acid and kept on ice for $30 \mathrm{~min}$. The precipitate was collected by centrifugation at $10000 \mathrm{~g}$ for $20 \mathrm{~min}$ and then washed twice by centrifugation in $1 \mathrm{ml}$ ice-cold $7.5 \%$ trichloroacetic acid. Phosphorylated proteins were analysed by SDS-PAGE according to Laemmli (1970) and by subsequent autoradiography.

Determination of protein concentration. Protein concentration was determined by the Lowry method, using BSA as a standard.

Statistical analysis. All mean values are shown with their calculated standard error (SE). Student's $t$-test was used to determine the significance of differences between controls and experimental groups; a $P$ value of 0.05 or less was considered statistically significant.

\section{RESULTS}

\section{Effect of $\alpha$-toxin on rabbit neutrophils}

To investigate the effect of $\alpha$-toxin on neutrophil adhesion to fibrinogen and on the chemiluminescence responses of rabbit neutrophils, neutrophils were incubated with various concentrations of the toxin at $37^{\circ} \mathrm{C}$ for $30 \mathrm{~min}$. As shown in Fig. $1(\mathrm{a}, \mathrm{c})$, toxin added in the range $2 \cdot 5-20 \mu \mathrm{g} \mathrm{ml}^{-1}$ induced adhesion of the cells to fibrinogen and chemiluminescence responses in a dose-dependent manner. The adhesion started 1-5 min after incubation when the cells were incubated with $20 \mu \mathrm{g} \alpha$-toxin $\mathrm{ml}^{-1}$, and was maximal after $20 \mathrm{~min}$ of incubation (data not shown). Formyl-Met-Leu-Pro (fMLP), which was used as a positive control, increased cell adhesion to fibrinogen in a dose-dependent manner (Fig. 1b). The toxin-induced chemiluminescence responses began about $1.5 \mathrm{~min}$ after the incubation of the cells with toxin concentrations less than $20 \mu \mathrm{g} \mathrm{ml}{ }^{-1}$, and maximal responses were observed about 4,5 and $7 \mathrm{~min}$ after incubation with 20, 10 and $2.5 \mu \mathrm{g} \alpha$-toxin $\mathrm{ml}^{-1}$, respectively (Fig. 1c). Toxin-induced chemiluminescence was completely inhibited by $0.5 \mu \mathrm{M}$ superoxide dismutase, whereas it was not inhibited significantly by $0.5 \mathrm{mM} \mathrm{N}_{3}^{-}\left({ }^{1} \mathrm{O}_{2}\right.$ quencher$), 20 \mu \mathrm{g}$ catalase $\mathrm{ml}^{-1}\left(\mathrm{H}_{2} \mathrm{O}_{2}\right.$ scavenger), or $50 \mathrm{mM}$ mannitol ( $\mathrm{HO}^{*}$ scavenger) (data not shown). Treatment of rabbit neutrophils with less than $50 \mu \mathrm{g} \alpha$-toxin $\mathrm{ml}^{-1}$ caused no release of lactate dehydrogenase from the cells. Therefore, it appears that the toxin does not harm the cells, as reported by Stevens et al. (1987). Toxin pretreated with $1 \mathrm{mM}$ EDTA, and the H148G variant toxin, which does not possess PLC or haemolytic activity (Nagahama et al., 1995), did not induce cell adhesion to fibrinogen or a chemiluminescence response (data not shown). We tested the ability of the $\alpha$-toxin-treated rabbit neutrophils to adhere to other extracellular matrix ligands, such as type I collagen and fibronectin. The toxin induced cell adhesion to these ligands in a dose-dependent manner (Fig. 1a). The adhesion of neutrophils to fibronectin was comparable with that to fibrinogen, but the toxininduced adhesion to type I collagen was about $30 \%$ of that to fibrinogen. It is likely that the toxin-induced adhesion of rabbit neutrophils is matrix-specific.
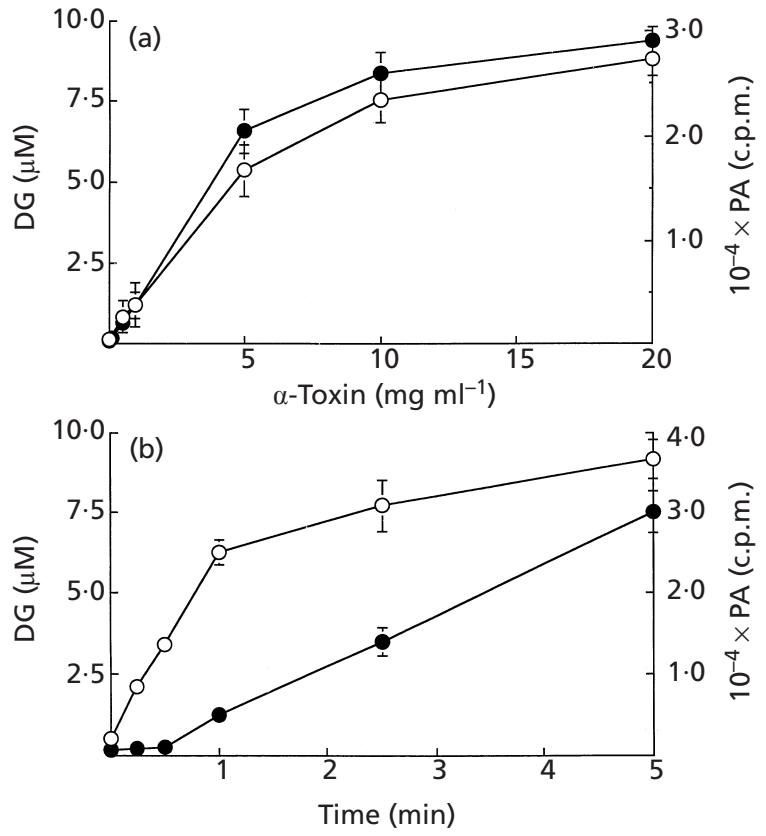

Fig. 2. Effect of $\alpha$-toxin on DG formation in neutrophils and PA formation in neutrophil lysates. (a) Rabbit neutrophils $\left(1.5 \times 10^{7} \mathrm{ml}^{-1}\right)$ or lysates were incubated with various concentrations of $\alpha$-toxin at $37{ }^{\circ} \mathrm{C}$ for $5 \mathrm{~min}$. DG $(O)$ and PA (๑) were determined as described in Methods. Values are means \pm SE for five or six experiments. (b) Rabbit neutrophils $\left(1.5 \times 10^{7} \mathrm{ml}^{-1}\right)$ or lysates were incubated with $10 \mu \mathrm{g} \alpha$ toxin $\mathrm{ml}^{-1}$ at $37^{\circ} \mathrm{C}$ for various periods. DG $(\bigcirc)$ and PA (O) were determined as described in Methods. Values are means + SE for five or six experiments. The lack of error bars indicates that the SE was smaller than the symbol.

\section{Effect of $\alpha$-toxin on phospholipid metabolism in rabbit neutrophils}

We have previously reported that $\alpha$-toxin induces haemolysis of rabbit erythrocytes through activation of phospholipid metabolism (Sakurai et al., 1993). Therefore, the effect of $\alpha$-toxin on DG formation in rabbit neutrophils and PA formation in the cell lysates was examined. Fig. 2(a) shows that $\alpha$-toxin in the range 1-20 $\mu \mathrm{g} \alpha$-toxin $\mathrm{ml}^{-1}$ induced formation of DG and PA in a dose-dependent manner. We then determined the time course of the $\alpha$-toxin-induced production of DG and PA (Fig. 2b). The formation of DG began within $30 \mathrm{~s}$ of the incubation and was maximal after $1 \mathrm{~min}$; formation of PA started $1 \mathrm{~min}$ after the incubation and gradually increased until at least $5 \mathrm{~min}$. Therefore, it appears that toxin-induced DG production was followed by PA production under the conditions tested.

\section{Effect of pertussis toxin, GTP $\gamma S$ and GDP $\beta$ S on the $\alpha$-toxin-induced events}

We have previously reported that $\alpha$-toxin-induced haemolysis and PA formation in rabbit erythrocytes is due to activation of endogenous PLC, via pertussis-toxin- 

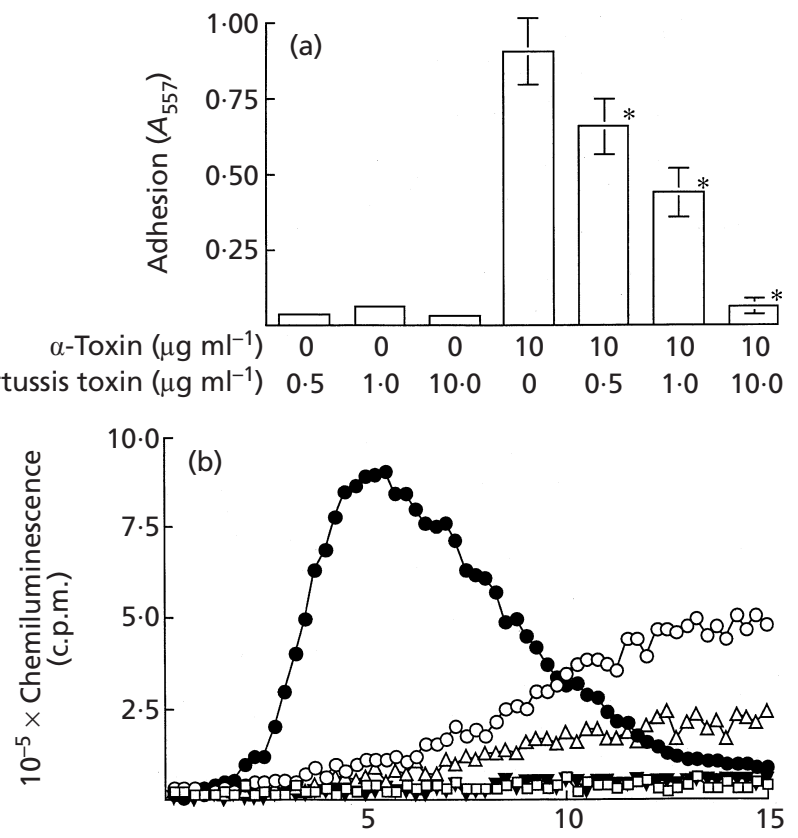

Fig. 3. Effect of pertussis toxin on $\alpha$-toxin-induced neutrophil adhesion and superoxide generation. (a) Rabbit neutrophils $\left(1.2 \times 10^{6} \mathrm{ml}^{-1}\right)$ were incubated with various concentrations of pertussis toxin at $37^{\circ} \mathrm{C}$ for $120 \mathrm{~min}$. Pertussis-toxin-treated neutrophils were incubated in fibrinogen-coated wells in the presence or absence of $\alpha$-toxin at $37^{\circ} \mathrm{C}$ for $20 \mathrm{~min}$. Adherent cells were determined as described in the Methods. Values are means \pm SE for five or six experiments. The lack of error bars indicate that the SE was smaller than the horizontal line of the bar. ${ }^{*}, P<0.05$ compared with adhesion induced by $\alpha$-toxin. (b) Rabbit neutrophils $\left(1.5 \times 10^{6} \mathrm{ml}^{-1}\right)$ were preincubated without $(\square)$ or with various concentrations of pertussis toxin $(O$, $1 \mu \mathrm{g} \mathrm{ml}^{-1} ; \triangle, 5 \mu \mathrm{g} \mathrm{ml}^{-1} ; \nabla, 10 \mu \mathrm{g} \mathrm{ml}^{-1}$ ) at $37^{\circ} \mathrm{C}$ for $120 \mathrm{~min}$. Pertussis toxin-treated neutrophils were incubated without $(\square)$ or with $20 \mu \mathrm{g} \alpha$-toxin $\mathrm{ml}^{-1}(\boldsymbol{0}, \bigcirc, \triangle, \boldsymbol{\nabla})$ at $37^{\circ} \mathrm{C}$ for various periods. The results from one of five experiments yielding similar results are shown.

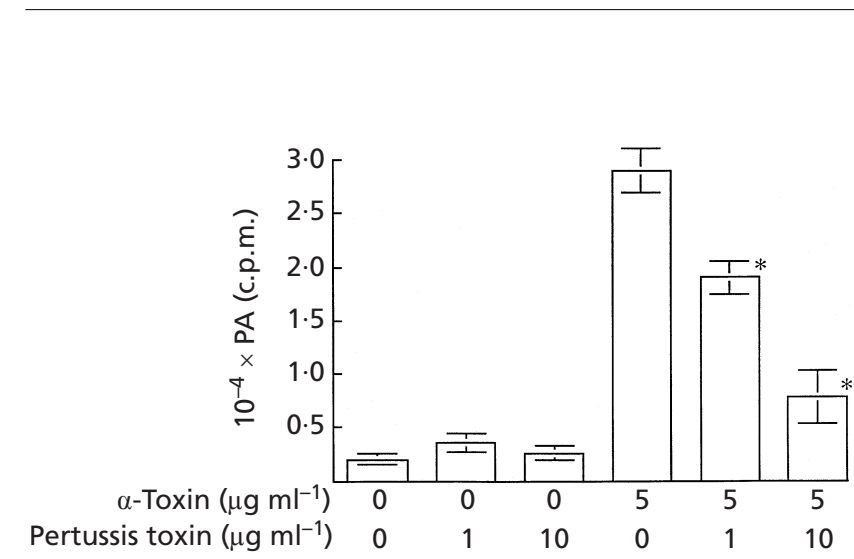

Fig. 4. Effect of pertussis toxin on $\alpha$-toxin-induced PA formation in neutrophil lysates. Rabbit neutrophils $\left(1.5 \times 10^{7} \mathrm{ml}^{-1}\right)$ were incubated with various concentrations of pertussis toxin at $37^{\circ} \mathrm{C}$ for $120 \mathrm{~min}$. Pertussis-toxin-treated neutrophils were lysed and then incubated with $\alpha$-toxin and $10 \mu \mathrm{Ci}\left[\gamma^{32} \mathrm{P}\right] \mathrm{ATP}$ at $37^{\circ} \mathrm{C}$ for $5 \mathrm{~min}$. PA was determined as described in Methods. Values are means \pm SE for five or six experiments. ${ }^{*}, P<0.05$, compared with PA formation induced by $\alpha$-toxin.

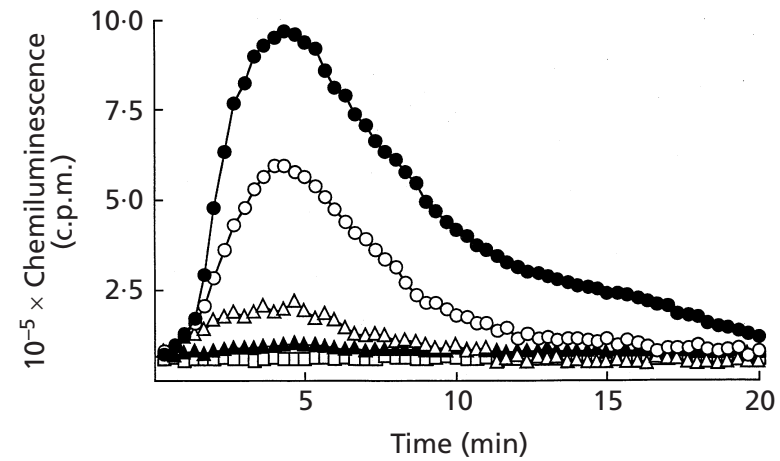

Fig. 5. Effect of GDP $\beta$ S on $\alpha$-toxin-induced superoxide generation in rabbit neutrophils. Rabbit neutrophils $\left(1.5 \times 10^{6} \mathrm{ml}^{-1}\right)$ were incubated without $(\square)$ or with $10 \mu \mathrm{g} \alpha$ toxin $\mathrm{ml}^{-1}(\bullet)$ in the presence of $\operatorname{GDP} \beta \mathrm{S}(\bigcirc, 50 \mu \mathrm{M} ; \triangle, 75 \mu \mathrm{M}$; $A, 100 \mu \mathrm{M})$ at $37^{\circ} \mathrm{C}$ for various periods and the chemiluminescence was measured by a chemiluminescence reader. The results from one of five experiments yielding similar results are shown.

Table 1. Effect of GTP $\gamma \mathrm{S}$ or GDP $\beta$ S on $\alpha$-toxin-induced PA formation in permeabilized neutrophil lysates

Permeabilized rabbit neutrophils $\left(1.5 \times 10^{7} \mathrm{ml}^{-1}\right)$ were preincubated with various concentrations of GTP $\gamma S$ or GDP $\beta S$ at $37^{\circ} \mathrm{C}$ for $30 \mathrm{~min}$ and then incubated with $\alpha$-toxin and $10 \mu \mathrm{Ci}$ $\left[\gamma-{ }^{32} \mathrm{P}\right] \mathrm{ATP}$ at $37^{\circ} \mathrm{C}$ for $5 \mathrm{~min}$. The mass of PA was determined as described in Methods. Data are expressed as a percentage of the control ( $\alpha$-toxin alone). Values are means \pm SE for five or six experiments.

\begin{tabular}{|lcc|}
\hline Treatment & PA (percentage of \\
& & \\
& & 100 \\
Control ( $\alpha$-toxin alone) & $1 \mu \mathrm{M}$ & $173 \pm 4 \dagger$ \\
GTP $\gamma$ S & $5 \mu \mathrm{M}$ & $653 \pm 6 \dagger$ \\
& $10 \mu \mathrm{M}$ & $786 \pm 5 \dagger$ \\
GDP $\beta S$ & $0 \cdot 02 \mu \mathrm{M}$ & $110 \pm 5$ \\
& $2 \mu \mathrm{M}$ & $40 \pm 4 \dagger$ \\
& $4 \mu \mathrm{M}$ & $32 \pm 5 \dagger$ \\
\hline
\end{tabular}

$\dagger P<0 \cdot 05$, compared with PA formation induced by the toxin alone.

sensitive GTP-binding protein, which is activated by the toxin (Sakurai et al., 1993, 1994; Ochi et al., 1996). Thus, we tested whether prior treatment of neutrophils with pertussis toxin affects $\alpha$-toxin-induced adhesion and chemiluminescence responses. As shown in Fig. 3(a, b), $\alpha$-toxin-induced adhesion and chemiluminescence responses in neutrophils pretreated with $1 \mu \mathrm{g}$ pertussis toxin $\mathrm{ml}^{-1}$ were about $50 \%$ as extensive as those induced by the toxin of untreated neutrophils, and the treatment with $10 \mu \mathrm{g}$ pertussis toxin $\mathrm{ml}^{-1}$ resulted in a complete loss of the reponses induced by $\alpha$-toxin. We then investigated the effect of pertussis toxin on $\alpha$-toxininduced PA formation. Fig. 4 shows that pretreatment of 


\section{(a)}
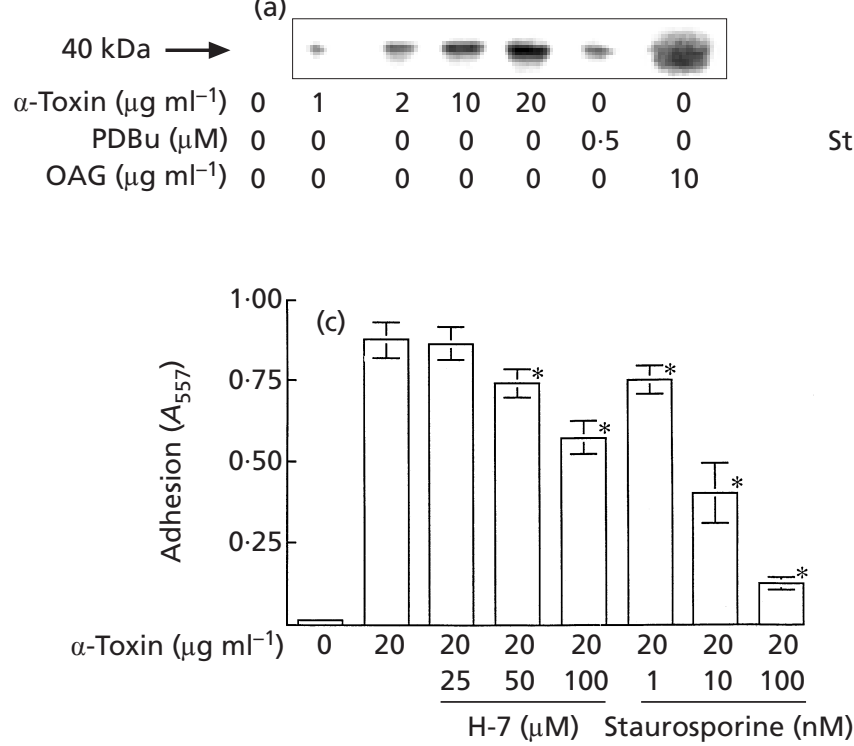

(b)
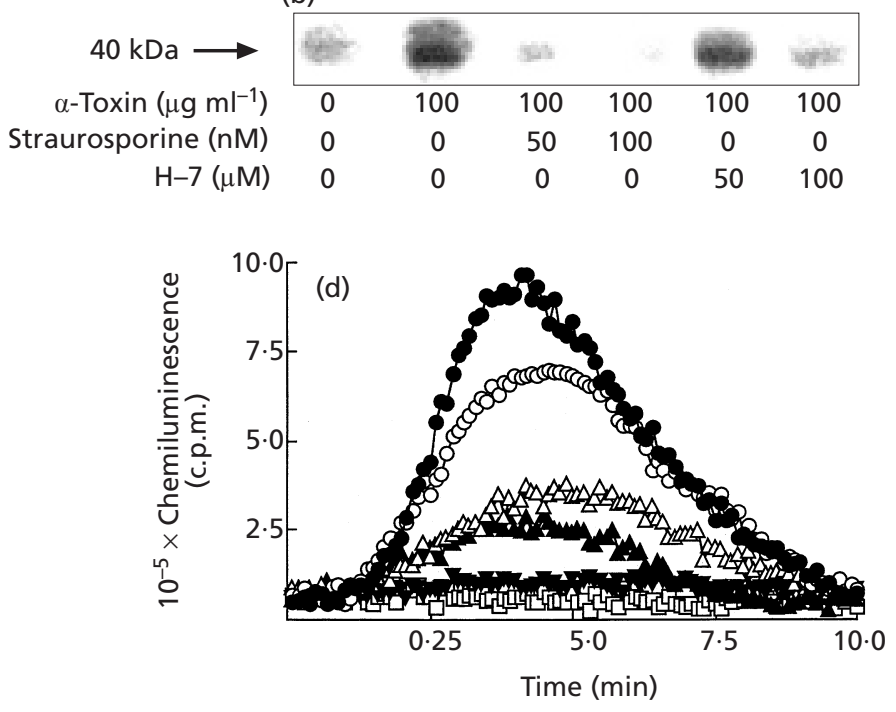

Fig. 6. $\alpha$-Toxin-induced phosphorylation of $40 \mathrm{kDa}$ protein and adhesion to fibrinogen. (a) Rabbit neutrophil

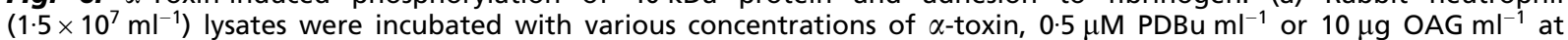
$37^{\circ} \mathrm{C}$ for $5 \mathrm{~min}$. Phosphorylated proteins were analysed by SDS-PAGE and autoradiography as described in Methods. The experiment was repeated with similar results. (b) Rabbit neutrophil $\left(1.5 \times 10^{7} \mathrm{ml}^{-1}\right)$ lysates were preincubated at $37^{\circ} \mathrm{C}$ for 15 min with various concentrations of protein kinase $C$ inhibitor (staurosporine or H-7) and then incubated with $\alpha$-toxin and $10 \mu \mathrm{Ci}\left[\gamma_{-}{ }^{32} \mathrm{P}\right] A T P \mathrm{ml}^{-1}$ at $37^{\circ} \mathrm{C}$ for $5 \mathrm{~min}$. Phosphorylated proteins were analysed by SDS-PAGE and autoradiography as described in Methods. The experiment was repeated with similar results. (c) Rabbit neutrophils $\left(1.2 \times 10^{6} \mathrm{ml}^{-1}\right)$ were preincubated with various concentrations of protein kinase $\mathrm{C}$ inhibitor ( $\mathrm{H}-7$ or staurosporine) at $37^{\circ} \mathrm{C}$ for 15 min and then incubated with $\alpha$-toxin in fibrinogen-coated wells at $37{ }^{\circ} \mathrm{C}$ for $20 \mathrm{~min}$. Adherent cells were determined as described in Methods. Values are means \pm SE for five or six experiments. ${ }^{*}, P<0.05$, compared with adhesion induced by $\alpha$-toxin. (d) Rabbit neutrophils $\left(1.5 \times 10^{6} \mathrm{ml}^{-1}\right)$ were incubated without $(\square)$ or with $10 \mu \mathrm{g} \alpha$-toxin $\mathrm{ml}^{-1}(\bullet)$ in the presence of $\mathrm{H}-7$ ( $\bigcirc$, $50 \mu \mathrm{M} ; \triangle, 100 \mu \mathrm{M})$ or staurosporine $(\Delta, 50 \mathrm{nM} ; \boldsymbol{\nabla}, 100 \mathrm{nM})$ at $37^{\circ} \mathrm{C}$ for various periods and the chemiluminescence was measured. The results from one of five experiments yielding similar results are shown.

neutrophil lysates with pertussis toxin inhibited $\alpha$-toxininduced PA formation in a dose-dependent manner, as reported previously. To obtain further evidence for a relationship between the toxin-induced events and the GTP-binding protein, the effect of GDP $\beta$ S on these toxin-induced events was examined. $\alpha$-Toxin was incubated with streptolysin-O-treated neutrophils in the presence of GDP $\beta$ S. The toxin-induced chemiluminescence responses in the presence of 50 and $75 \mu \mathrm{M}$ GDP $\beta S$ were about 60 and $16 \%$ of the responses seen in the absence of GDP $\beta$ S, respectively (Fig. 5). Furthermore, GTP $\gamma$ S significantly enhanced the toxin-induced responses (data not shown). When the toxin was incubated with the lysates which had been preincubated in the presence of GTP $\gamma S$ or GDP $\beta S$, the formation of PA increased with increase in the dose of GTP $\gamma S$ and decreased with increase in the dose of GDP $\beta$ S (Table 1).

\section{Action of $\alpha$-toxin on DG-activated protein kinase C}

Hayakawa et al. (1986) reported that the production of the superoxide anion in human neutrophils is stimulated through phosphorylation of 44-48 kDa proteins by DGactivated protein kinase $\mathrm{C}$. It also was reported that aggregation of human platelets is induced by phosphorylation of a $40 \mathrm{kDa}$ protein by $\mathrm{DG}$-activated protein kinase C (de Chaffoy de Courcelles et al., 1985 ; Nunn \& Watson, 1987). We examined whether neutrophil adhesion and chemiluminescence responses were induced on addition of 1-oleoyl-2-acetyl-sn-glycerol (OAG, an analogue of DG). Both responses increased linearly with an increase in the dose of OAG and phorbol-12,13dibutyrate $(\mathrm{PDBu})$, which activate protein kinase $\mathrm{C}$ (data not shown). One to twenty micrograms of $\alpha$-toxin was incubated with neutrophil lysates and $\left[\gamma^{32} \mathrm{P}\right] \mathrm{ATP}$, and the phosphorylated proteins were analysed by SDSPAGE. Fig. 6(a) shows that the toxin induced phosphorylation of a $40 \mathrm{kDa}$ protein in neutrophils in a dosedependent manner. When neutrophil lysates were treated with $10 \mu \mathrm{g}$ toxin $\mathrm{ml}^{-1}$, the $40 \mathrm{kDa}$ protein was strongly phosphorylated, but phosphorylation of 47,57 and $65 \mathrm{kDa}$ proteins was less than $15 \%$ of that of the $40 \mathrm{kDa}$ protein. OAG and $\mathrm{PDBu}$ also stimulated the phosphorylation of a $40 \mathrm{kDa}$ protein in the neutrophils. The effect of staurosporine and H-7, which inhibit protein kinase $\mathrm{C}$, on the phosphorylation of the $40 \mathrm{kDa}$ protein by the toxin was also investigated. Fig. $6(\mathrm{~b})$ shows that $\mathrm{H}-7$ (50 and $100 \mu \mathrm{M})$ and staurosporine (50 and $100 \mathrm{nM}$ ) inhibited phosphorylation of the $40 \mathrm{kDa}$ protein by the toxin in a dose-dependent manner. Furthermore, H-7 (>50 $\mu \mathrm{M})$ and staurosporine (20$100 \mathrm{nM}$ ) blocked the toxin-induced adhesion (Fig. 6c) 
and chemiluminescence responses in a dose-dependent manner (Fig. 6d). In addition, $25 \mu \mathrm{M}$ chelerythrine, a protein kinase $\mathrm{C}$ inhibitor, significantly inhibited the toxin-induced events (data not shown). On the other hand, treatment of $\alpha$-toxin with these inhibitors at $37^{\circ} \mathrm{C}$ for $15 \mathrm{~min}$ had no effect on the PLC activity of the toxin.

\section{DISCUSSION}

Gas gangrene caused by C. perfringens is characterized by a rapidly spreading oedema and tissue necrosis, associated with the growth of the micro-organism (Stevens, 2000). Several studies have found aggregates of leukocytes in vessels at the borders of the necrotic tissue and that leukocytes were absent from the necrotic tissue (Stevens et al., 1997; Bryant et al., 2000a). This phenomenon could be a result of the impairment of leukocytes by exotoxins produced by C. perfringens, or of the expression of adhesion molecules and cytokines in vivo. $\theta$-Toxin is known to be cytotoxic to leukocytes (Stevens et al., 1987; Rossjohn et al., 1999), suggesting that it contributes to the paucity of leukocytes in the necrotic tissue. However, this does not explain why leukocytes accumulate in vessels at the borders of necrotic tissue.

It has been reported that $\alpha$-toxin induced the expression of E-selectin and ICAM-1 in human umbilical vein endothelial cells (Bryant \& Stevens, 1996), as well as the expression of P-selectin in vivo (Bunting et al., 1997; Bryant et al., 2000a). It has also been reported that intramuscular injection of the toxin induced growth of intravascular aggregates of activated platelets, fibrin and leukocytes in a manner dependent on the fibrinogen receptor glycoprotein IIb/IIIa (gpIIb/IIIa; Bryant et al., 2000a). However, Ellemor et al. (1999) reported that infection with C. perfringens did not induce the expression of adhesion molecules, such as ICAM-1, in vivo. In addition, it is known that selectin-dependent adhesion of leukocytes does not lead to firm adhesion unless another set of adhesion molecules is engaged (Albelda et al., 1994), and that the firm adhesion of neutrophils requires activation of the $\beta 2$ (CD18) integrin family, resulting in binding to one of the intercellular adhesion molecules on the surface of endothelial cells (Ley, 1996). If the exotoxins produced by C. perfringens activate cellular functions in neutrophils adhered to biological surfaces, neutrophils which are exposed to the toxin at the borders of the necrotic tissue would bind to adjacent vessels at the borders. In the present study, we demonstrated that treatment of neutrophils with $\alpha$ toxin enhanced their adhesion to fibrinogen and fibronectin, but resulted in weak adhesion to collagen. It is known that the adhesion of neutrophils to fibrinogen is mediated by a group of $\beta 2$ and $\beta 3$ integrins (Humphries, 2000). Taking these findings into consideration, the toxin-induced cell adhesion suggests that the toxin induces activation of $\beta 2$ integrin(s) on neutrophils and the expression of integrin ligands, such as ICAM-1, on the surface of endothelial cells. Therefore, it is possible that the toxin-induced adhesion of the cells to matrixes promotes the growth of intravascular aggregates, as reported by Bryant et al. (2000a).

It has been reported that $\alpha$-toxin induced a respiratory burst in guinea pigs (Patriarca et al., 1970) and in human polymorphonuclear leukocytes (PMNLs) (Kaplan et al., 1972; König et al., 1997; Yan \& Novak, 1999), potentiated the chemiluminescence response to opsonized zymosan in human PMNLs, and elicited superoxide production in bovine neutrophils (Styrt et al., 1989). $\alpha$ Toxin also induced adhesion of the cells to matrix ligands, such as fibrinogen and fibronectin, and the production of reactive oxygen intermediates in rabbit neutrophils. Inhibition of MCLA chemiluminescence by superoxide dismutase, but not by $\mathrm{N}_{3}^{-}$, indicated that $\mathrm{O}_{2}^{-}$ elicited MCLA luminescence without the involvement of ${ }^{1} \mathrm{O}_{2}$, i.e. the production of $\mathrm{O}_{2}^{-}$in rabbit neutrophils. The results provide evidence of a relationship between intracellular transduction events (e.g. activation of GTPbinding protein, endogenous PLC and protein kinase $\mathrm{C}$ ) and events such as $\mathrm{O}_{2}^{-}$production and adhesion of the cells to these matrix ligands in toxin-activated rabbit neutrophils. The production of DG and PA induced by the toxin followed these biological events.

Pertussis toxin inhibited toxin-induced PA formation, adhesion and $\mathrm{O}_{2}^{-}$production in neutrophils and GTP $\gamma \mathrm{S}$ stimulated these events, but GDP $\beta S$ inhibited them. These observations suggest that the activation of phospholipid metabolism plays an important role in these events, which are induced by the toxin, and is dependent on activation of the pertussis-toxin-sensitive GTPbinding protein. Ohta et al. (1985) reported that fMLP induced production of the superoxide anion which was mediated by the pertussis-toxin-sensitive GTP-binding protein present in human neutrophils. In addition, we have reported that $\alpha$-toxin induced the metabolism of phospholipid and haemolysis through activation of the pertussis toxin-sensitive GTP-binding protein in rabbit erythrocytes (Sakurai et al., 1994; Ochi et al., 1996). The process of toxin-induced neutrophil activation is supported by the results obtained with fMLP and by the haemolysis induced by the toxin.

$\alpha$-Toxin stimulated the production of DG and PA with phosphorylation of a $40 \mathrm{kDa}$ protein in rabbit neutrophils. However, OAG and PDBu, both protein kinase $\mathrm{C}$ activators, activated cell adhesion and $\mathrm{O}_{2}^{-}$production, but did not enhance DG and PA production. The results show that the phosphorylation of the $40 \mathrm{kDa}$ protein, induced by these activators, occurred downstream of the toxin-induced phospholipid metabolism. In addition, protein kinase $\mathrm{C}$ inhibitors inhibited the toxin-induced $\mathrm{O}_{2}^{-}$production, cell adhesion and phosphorylation of the $40 \mathrm{kDa}$ protein. It appears that the toxin-induced adhesion is closely related to the production of DG, a protein kinase activator, through activation of phospholipid metabolism. Several studies have shown that $\alpha$ toxin can elicit the activation of protein kinase $\mathrm{C}$ in rat skeletal muscle (Henriksen et al., 1989) and mouse epidermal HEL-37 cells (Jones \& Murray, 1986). Grzeskowiak et al. (1985) reported that the neutrophil 
responses induced by the toxin, activation of a respiratory burst and secretion of specific granules, were dependent on the formation of DG with the breakdown of phospholipids. They hypothesized the involvement in the neutrophil responses of protein kinase C. Our result was consistent with the hypothesis proposed by Grzeskowiak et al. (1985). Yan \& Novak (1999) reported that treatment of human neutrophils with tumour necrosis factor $\alpha$ and fMLP, which stimulated adhesion of the cells to fibrinogen, resulted in the phosphorylation of cellular proteins with molecular masses of approximately $115 \mathrm{kDa}$. Hayakawa et al. (1986) reported that treatment of human neutrophils with DG caused the production of the superoxide anion and the phosphorylation of proteins with molecular masses of $44-48 \mathrm{kDa}$. Fuchs et al. (1997) reported that phorbol ester induced phosphorylation of a $40 \mathrm{kDa}$ protein in HL60 cells that had differentiated into neutrophils, and that the protein phosphorylation was closely related to the kinetics of $\mathrm{O}_{2}^{-}$production. Therefore, the toxin-induced adhesion and $\mathrm{O}_{2}^{-}$production appears to be involved in the phosphorylation of cellular proteins in neutrophils. The phosphorylated $40 \mathrm{kDa}$ protein was reported to be p40phox, a soluble component of NADPH oxidase (Fuchs et al., 1997; Babior, 1999). However, Bianca et al. (1999) reported that antigen-antibody reactions of antibodies against the components of NADPH oxidase were species-specific and identified human and mouse NADPH oxidase components. Rabbit NADPH oxidase components, however, have not yet been isolated. Therefore, in the present study, the phosphorylated $40 \mathrm{kDa}$ protein in rabbit neutrophils treated with the toxin was difficult to identify.

\section{ACKNOWLEDGEMENTS}

This research was supported in part by a Grant-in-Aid for Scientific Research from the Ministry of Education, Culture, Sports, Science and Technology, Japan. We thank K. Kobayashi and S. Ikari for their technical assistance.

\section{REFERENCES}

Albelda, S. M., Smith, C. W. \& Ward, P. A. (1994). Adhesion molecules and inflammatory injury. FASEB J 8, 504-512.

Awad, M. M., Bryant, A. E., Stevens, D. L. \& Rood, J. I. (1995). Virulence studies on chromosomal alpha-toxin and theta-toxin mutants constructed by allelic exchange provide genetic evidence for the essential role of alpha-toxin in Clostridium perfringensmediated gas gangrene. Mol Microbiol 5, 191-202.

Babior, B. M. (1999). NADPH oxidase: an update. Blood 93, 1464-1476.

Bhakdi, S. \& Tranum-Jensen, J. (1988). Damage to cell membranes by pore-forming bacterial cytolysins. Prog Allergy 40, 1-43.

Bianca, V. D., Dusi, S., Bianchini, E., Dal Pra, I. \& Rossi, F. (1999). $\beta$-Amyloid activates the $\mathrm{O}_{2}^{-}$forming NADPH oxidase in microglia, monocytes, and neutrophils. A possible inflammatory mechanism of neuronal damage in disease. J Biol Chem 274, 15493-15499.

Bryant, A. E. \& Stevens, D. L. (1996). Phospholipase C and perfringolysin $\mathrm{O}$ from Clostridium perfringens upregulate en- dothelial cell-leukocyte adherence molecule 1 and intercellular leukocyte adherence molecule 1 expression and induce interleukin-8 synthesis in cultured human umbilical vein endothelial cells. Infect Immun 64, 358-362.

Bryant, A. E., Chen, R. Y., Nagata, Y., Wang, Y., Lee, C. H., Finegold, S., Guth, P. H. \& Stevens, D. L. (2000a). Clostridial gas gangrene. I. Cellular and molecular mechanisms of microvascular dysfunction induced by exotoxins of Clostridium perfringens. J Infect Dis 182, 799-807.

Bryant, A. E., Chen, R. Y., Nagata, Y., Wang, Y., Lee, C. H., Finegold, S., Guth, P. H. \& Stevens, D. L. (2000b). Clostridial gas gangrene. II. Phospholipase C-induced activation of platelet gpIIbIIIa mediates vascular occlusion and myonecrosis in Clostridium perfringens gas gangrene. J Infect Dis 182, 808-815.

Bunting, M., Lorant, D. E., Bryant, A. E., Zimmerman, G. A., McIntyre, T. M., Stevens, D. L. \& Prescott, S. M. (1997). Alpha toxin from Clostridium perfringens induces proinflammatory changes in endothelial cells. J Clin Invest 100, 565-574.

de Chaffoy de Courcelles, D. C., Roevens, P. \& Van Belle, H. (1985). R59022, a diacylglycerol kinase inhibitor. Its effect on diacylglycerol and thrombin-induced $\mathrm{C}$ kinase activation in the intact platelet. J Biol Chem 260, 15762-15770.

Ellemor, D. M., Baird, R. N., Awad, M. M., Boyd, R. L., Rood, J. I. \& Emmins, J. J. (1999). Use of genetically manipulated strains of Clostridium perfringens reveals that both alpha-toxin and thetatoxin are required for vascular leukostasis to occur in experimental gas gangrene. Infect Immun 67, 4902-4907.

Fuchs, A., Bouin, A. P., Rabilloud, T. \& Vignais, P. V. (1997). The 40-kDa component of the phagocyte NADPH oxidase (p40phox) is phosphorylated during activation in differentiated HL60 cells. Eur J Biochem 249, 531-539.

Fujii, Y. \& Sakurai, J. (1989). Contraction of the rat isolated aorta caused by Clostridium perfringens alpha toxin (phospholipase C) : evidence for the involvement of arachidonic acid metabolism. Br J Pharmacol 97, 119-124.

Fujii, Y., Nomura, S., Oshita, Y. \& Sakurai, J. (1986). Excitatory effect of Clostridium perfringens alpha toxin on the rat isolated aorta. Br J Pharmacol 88, 531-539.

Grzeskowiak, M., Della Bianca, V., De Togni, P., Papini, E. \& Rossi, F. (1985). Independence with respect to $\mathrm{Ca}^{2+}$ changes of the neutrophil respiratory and secretory response to exogenous phospholipase $\mathrm{C}$ and possible involvement of diacylglycerol and protein kinase C. Biochim Biophys Acta 844, 81-90.

Hayakawa, T., Suzuki, K., Suzuki, S., Andrews, P. C. \& Babior, B. M. (1986). A possible role for protein phosphorylation in the activation of the respiratory burst in human neutrophils. Evidence from studies with cells from patients with chronic granulomatous disease. J Biol Chem 261, 9109-9115.

Henriksen, E. J., Rodnick, K. J. \& Holloszy, J. O. (1989). Activation of glucose transport in skeletal muscle by phospholipase $\mathrm{C}$ and phorbol ester. Evaluation of the regulatory roles of protein kinase C and calcium. J Biol Chem 264, 21536-21543.

Hofman, P., Le Negrate, G., Mograbi, B., Hofman, V., Brest, P., Alliana-Schmid, A., Flatau, G., Boquet, P. \& Rossi, B. (2000). Escherichia coli cytotoxic necrotizing factor-1 (CNF-1) increases the adherence to epithelia and the oxidative burst of human polymorphonuclear leukocytes but decreases bacteria phagocytosis. J Leukoc Biol 68, 522-528.

Humphries, M. J. (2000). Integrin structure. Biochem Soc Trans 28, 311-339.

Jones, M. J. \& Murray, A. W. (1986). Effect of membrane perturbation on protein kinase $\mathrm{C}$ activation: treatment with 
exogenous phospholipase $\mathrm{C}$ decreases translocation of enzyme to cellular membranes. Biochem Biophys Res Commun 136, 1083-1089.

Kaplan, S. S., Finch, S. C. \& Basford, R. E. (1972). Polymorphonuclear leukocyte activation: effects of phospholipase C. Proc Soc Exp Biol Med 140, 540-543.

König, B., Vasil, M. L. \& König, W. (1997). Role of hemolytic and nonhemolytic phospholipase C from Pseudomonas aeruginosa for inflammatory mediator release from human granulocytes. Int Arch Allergy Immunol 112, 115-124.

Kurioka, S. \& Matsuda, M. (1976). Phospholipase C assay using $p$ nitrophenylphosphoryl-choline together with sorbitol and its application to studying the metal and detergent requirement of the enzyme. Anal Biochem 75, 281-289.

Laemmli, U. K. (1970). Cleavage of structural proteins during the assembly of the head of bacteriophage T4. Nature 227, 680-685.

Ley, K. (1996). Molecular mechanisms of leukocyte recruitment in the inflammatory process. Cardiovasc Res 32, 733-742.

Nagahama, M., Okagawa, Y., Nakayama, T., Nishioka, E. \& Sakurai, J. (1995). Site-directed mutagenesis of histidine residues in Clostridium perfringens alpha-toxin. J Bacteriol 177, 11791185.

Nakano, M. (1990). Determination of superoxide radical and singlet oxygen based on chemiluminescence of luciferin analogs. Methods Enzymol 186, 585-591.

Nishida, A., Kimura, H., Nakano, M. \& Goto, T. (1989). A sensitive and specific chemiluminescence method for estimating the ability of human granulocytes and monocytes to generate $\mathrm{O}_{2}^{-}$. Clin Chim Acta 179, 177-181.

Nunn, D. L. \& Watson, S. P. (1987). A diacylglycerol kinase inhibitor, R59022, potentiates secretion by and aggregation of thrombin-stimulated human platelets. Biochem J 243, 809-813.

Ochi, S., Hashimoto, K., Nagahama, M. \& Sakurai, J. (1996). Phospholipid metabolism induced by Clostridium perfringens alpha-toxin elicits a hot-cold type of hemolysis in rabbit erythrocytes. Infect Immun 64, 3930-3933.

Ohta, H., Okajima, F. \& Ui, M. (1985). Inhibition by islet-activating protein of a chemotactic peptide-induced early breakdown of inositol phospholipids and $\mathrm{Ca}^{2+}$ mobilization in guinea pig neutrophils. J Biol Chem 260, 15771-15780.

Patriarca, P., Zatti, M., Cramer, R. \& Rossi, F. (1970). Stimulation of the respiration of polymorphonuclear leucocytes by phospholipase C. Life Sci 9, 841-849.

Robb-Smith, A. T. H. (1945). Tissue changes induced by $\mathrm{Cl}$. welchii type A filtrates. Lancet 2, 362-368.

Rossjohn, J., Tweten, R. K., Rood, J. I. \& Parker, M. W. (1999). Perfringolysin O. In The Comprehensive Sourcebook of Bacterial
Protein Toxins, 2nd edn, pp. 496-510. Edited by J. E. Alouf \& J. H. Freer. London: Academic Press.

Sakurai, J. (1995). Major toxins of Clostridium perfringens. Rev Med Microbiol 6, 175-185.

Sakurai, J., Fujii, Y. \& Shirotani, M. (1990). Contraction induced by Clostridium perfringens alpha toxin in the isolated rat ileum. Toxicon 28, 411-418.

Sakurai, J., Ochi, S. \& Tanaka, H. (1993). Evidence for coupling of Clostridium perfringens alpha-toxin-induced hemolysis to stimulated phosphatidic acid formation in rabbit erythrocytes. Infect Immun 61, 3711-3718.

Sakurai, J., Ochi, S. \& Tanaka, H. (1994). Regulation of Clostridium perfringens alpha-toxin-activated phospholipase $\mathrm{C}$ in rabbit erythrocyte membranes. Infect Immun 62, 717-721.

Sakurai, J., Nagahama, M. \& Ochi, S. (1997). Major toxins of Clostridium perfringens. J Toxicol Toxin Rev 16, 195-214.

Stevens, D. L. (2000). The pathogenesis of clostridial myonecrosis. Int J Med Microbiol 290, 497-502.

Stevens, D. L., Mitten, J. \& Henry, C. (1987). Effect of $\alpha$ and $\theta$ toxins from Clostridium perfringens on human polymorphonuclear leukocytes. J Infect Dis 156, 324-333.

Stevens, D. L., Tweten, R. K., Awad, M. M., Rood, J. I. \& Bryant, A. E. (1997). Clostridial gas gangrene: evidence that $\alpha$ and $\theta$ toxins differentially modulate the immune response and induce acute tissue necrosis. J Infect Dis 176, 189-195.

Styrt, B., Walker, D. \& White, J. C. (1989). Neutrophil oxidative metabolism after exposure to bacterial phospholipase C. J Lab Clin Med 114, 51-57.

Titball, R. W. (1993). Bacterial phospholipase C. Microbiol Rev 57, 347-366.

Titball, R. W. (1997a). Bacterial phospholipase. Trends Microbiol 7, 265.

Titball, R. W. (1997b). Clostridial phospholipases. In Clostridia: Molecular Biology and Pathogenesis, pp. 223-242. Edited by J. I. Rood, B. A. McClane, J. G. Songer \& R. W. Titball. London: Academic Press.

Titball, R. W. (1999). Membrane-damaging and cytotoxic phospholipases. In The Comprehensive Sourcebook of Bacterial Protein Toxins, 2nd edn, pp. 310-329. Edited by J. E. Alouf \& J. H. Freer. London: Academic Press.

Yan, S. R. \& Novak, M. J. (1999). Beta2 integrin-dependent phosphorylation of protein-tyrosine kinase Pyk2 stimulated by tumour necrosis factor alpha and fMLP in human neutrophils adherent to fibrinogen. FEBS Lett 451, 33-38.

Received 21 March 2001; revised 23 July 2001; accepted 20 September 2001. 